\title{
Preventing transfusion associated hyperkalemia in pediatric cardiac surgery : Measure The Levels of Potassium in Packed Red Blood Cells Before Using - invited Commentary
}

\author{
Ali Baran Budak ${ }^{1}$ \\ ${ }^{1}$ Başkent Üniversitesi Tip Fakültesi
}

November 6, 2021

\begin{abstract}
The authors present an revolutionary study aiming to evaluate the effect of alterations in potassium concentrations in transfused packed red blood cells (PRBC) on neonate and infant potassium levels after congenital cardiac surgery. By establishing a strict protocol which restricts the rate of transfusion, the age of the transfused PRBC, and not transfusing a PRBC with a potassium level above $15 \mathrm{mmol} / \mathrm{L}$, they accomplished to suggest a safe and easy way for preventing transfusion associated hyperkalemia.

\section{Hosted file}

JOCS BARAN after edit.doc available at https://authorea.com/users/444781/articles/544438preventing-transfusion-associated-hyperkalemia-in-pediatric-cardiac-surgery-measure-thelevels-of-potassium-in-packed-red-blood-cells-before-using-invited-commentary
\end{abstract}

